\title{
MARKETING OF BORDER TOWNS ON THE EXAMPLE OF SELECTED DESTINATIONS IN THE BORDERLAND OF THE CZECH REPUBLIC AND POLAND
}

\author{
Marie GABRYŠOVÁ ${ }^{1 *}$, Wiesław CIECHOMSKI ${ }^{2}$ \\ ${ }^{1}$ Hornoslezská vysoká škola obchodní Zahraniční fakulta v Ostravě (Katowice School of Economics, Ostrava \\ branch); gabrysova@gmail.com, ORCID: 0000-0002-7273-4762 \\ ${ }^{2}$ University of Economics in Poznań; w.ciechomski@ue.poznan.pl, ORCID: 0000-0002-2310-8378 \\ * Correspondence author
}

Purpose: The paper aims to identify the extent to which city marketing has been implemented in selected Czech cities in the Moravian-Silesian Region as well as the tools that are used for managing city development.

Design/methodology/approach: The research was carried out in the following cities of the Czech Republic: Bohumín, Bruntál, Frýdek-Místek, Krnov, Opava, Ostrava and Třinec. The respondents were representatives of municipal authorities, and the method of individual indepth interviews (IDI) was used.

Findings: Territorial marketing is going through various phases in its evolution. It is constantly being enriched with new forms and tools of communication with the environment, including those related to modern Internet media and innovative mobile applications. The authorities of the cities subjected to in-depth analyses are aware of the challenges ahead. Competition for limited resources, such as investor funding or tourism income, will be won by those cities whose authorities manage to develop and implement effective marketing strategies ahead of their rivals.

Originality/value: The article discusses the advancement of selected place marketing tools used in the four analysed towns in the Polish-Czech borderland.

Keywords: City marketing, place marketing.

Category of the paper: Research paper.

\section{Introduction}

Marketing is a concept oriented to the market, in which at least three elements, two market entities which are parties in an exchange (suppliers and customers) and the object of exchange (products), are essential for an exchange process to occur (Lazorko, Niedzielska, 2011, p. 15). Market orientation means that all activities in the area of place marketing should be based on 
the requirements, needs, preferences and expectations of various groups of stakeholders connected with a given territorial unit (Makarski, Kuźniar, 2009, p. 28). Contemporary territorial units such as cities, municipalities and regions constantly compete with one another, just like companies do. For the purpose of this competition, their authorities use a wide spectrum of tools, the effectiveness and efficiency of which is determined by many factors (Ciechomski, 2017, p. 120). In the reality of globalization, the expansion of modern telecommunication and information technologies, the expansion of social media as well as other profound socio-economic changes, local governments are faced with a number of new challenges related to the optimization of promotional activities.

\section{City marketing}

The idea of city marketing management is not new. One of the first marketing theorists to describe the specificity of city marketing was Philip Kotler. He studied the activities of non-profit institutions and defined place marketing as a set of activities that can create, maintain and change attitudes or behaviours towards selected destinations. The aim of place marketing understood in this way should be to attract new residents, tourists as well as investors (Toporská, 2015, p. 33).

City marketing can also be defined as a concept supporting the cooperative and creative development of cities, aimed at increasing the attractiveness of a city in a predefined area (Rumpel, 2002, p. 177). The purpose of its implementation is to increase the quality of services provided to selected target groups of the population. This task should be achieved through institutionalized communication and by developing partnerships between the interested parties.

The development of city marketing is determined primarily by the constantly deepening and intensifying competition between cities. This requires local governments to undertake certain actions which take into account the preferences and expectations of their customers, i.e. the target groups (residents, tourists, and investors). Czech author J. Ježek reports that almost $75 \%$ of cities use city marketing (Toporská, 2015, p. 33).

Groups of internal and external stakeholders which are of particular importance with regard to city marketing are presented in Figure 1. These groups of stakeholders are the target markets for place marketing activities. Identifying these groups is crucial for the effective creation of a city's offer (Ciechomski, Romanowski, 2016, p. 82). 


\begin{tabular}{|l|l|}
\hline \multicolumn{1}{|c|}{ Internal stakeholders } & \multicolumn{1}{c|}{ External stakeholders } \\
\hline 1. Permanent and occasional residents (students, & 1. Domestic tourists \\
seasonal workers) & 2. Foreign tourists \\
2. Local entrepreneurs and investors & 3. Potential residents \\
3. Members of local authorities & 4. Short-term visitors \\
4. Employees and activists of local government at & 5. Domestic and foreign entrepreneurs \\
various levels & 6. Domestic and foreign investors \\
5. Employees of public utility companies and & 7. Highly-qualified employees \\
institutions & 8. Central authorities \\
6. Local organizations and institutions & 9. Government organizations and agencies \\
7. Representatives of other local lobbies & 10. National and foreign institutions \\
\hline
\end{tabular}

Figure 1. Stakeholder groups in city marketing. Source: own compilation based on: Florek, 2006, p. 76.

The most important entities in a settlement unit are the residents, as they co-create the local market. Nevertheless, territorial marketing cannot be limited only to this group of stakeholders (Ciechomski, Romanowski, 2013, p. 63). Targeting the offer, which in the case of a territorial unit is very wide, at correctly identified market segments determines the effectiveness of marketing activities. In city marketing, the customers are the entities that "buy" the idea, the image, the future benefits, or the possibility of settling down or running a business in a given destination. The most important customers of a territorial unit include potential entrepreneurs who want to set up an enterprise in a given area, and potential investors who are willing to address such needs as access to up-to-date and reliable information; the proper functioning of public institutions; technical infrastructure; the development of business-related initiatives; the creation and development of various projects and innovative initiatives in a given area, etc. Potential investors, for example those in the financial and housing markets (including developers), expect the authorities to be cooperative, to efficiently prepare the necessary documentation, e.g. local development plans, and to offer them other incentives, for example tax relief (Duczkowska-Piasecka, 2013, p. 145).

When considering the tasks of marketing, it is often emphasized that it plays a strategic role in the activities undertaken by local governments with regard to the functioning of modern cities and regions. Constant development of urban organisms and of the forms and instruments of communication with stakeholders is both a priority and a necessity. A city or municipality must adequately respond to new challenges and conditions, which in practice means that at the appropriate time the authorities should identify possible opportunities and threats, and be prepared to take both anticipatory and remedial actions (Striš, Vodák, Kubin, 2009, p. 390).

\section{Stages in the development of city marketing}

The phases in the development of city marketing are presented by J. Ježek. These are based on the work of Kravatzis (2005), who distinguished the following three development phases of city marketing: 
1. The phase of fragmentary promotional activities.

During this period, often referred to in the literature as the "first generation", marketing in cities was used to attract new residents, investors and tourists; and through the use of simple promotional tools highlighted specific attractions of the city, for example the low cost of living.

2. The phase in which marketing mix tools are gradually included in city marketing.

Identity and image become crucial in this phase of city marketing, because not only creating but also maintaining a positive image of the city are perceived as an important tool for attracting selected target groups to the city.

3. The branding phase.

Branding, i.e. creating a city's brand, is the last phase in the development of city marketing. In this case, the various actions undertaken as part of place marketing are aimed at creating the city's brand that aims to foster emotional and psychological bonds with the city. Although place branding is a relatively well-known concept abroad, in the Czech Republic many city officials are still not familiar with it, or understand this concept in a different way. This issue will be discussed in more detail later in this paper. Even if the authorities of some cities work on the implementation of place marketing activities, their actions are often incoherent, selective and incomplete (Ježek, 2010, p. 123).

The three phases of city marketing mentioned above indicate a long-term trend, according to which the implemented activities become more focused and specialized with each successive phase.

Despite significant progress in developing the discipline of city marketing, it has still not been possible to determine all the theoretical criteria that would lead to it being established as a new sub-discipline within marketing. Nevertheless, some authors agree that general marketing knowledge cannot be simply transferred to city marketing mechanically and without modifications (Toporská, 2015, pp. 38-39). In the literature devoted to this concept, there are many studies that explain its theory, but none of the works describes the issue in a complete and comprehensive manner. Some attempts to comprehensively explain city marketing are more utilitarian, while others are more theoretical and try to explain its complex structure.

\section{City brand and its positioning in the consciousness of promotion-mix recipients}

A city's brand should promise benefits to its recipients - residents, tourists and investors through a set of associations related to the city. A city brand is based on the following components: 
1. Destination - physical attributes of the city, its location, beauty, and climate;

2. People - hospitality of the residents, their empathy and attitude towards visitors, a sense of security, openness to people with a different skin colour, language, religion or views;

3. Potential - infrastructural, economic and educational chances and opportunities offered by the city to investors, newcomers, immigrants and other stakeholders;

4. Standing - international status and position of the city;

5. Living conditions - the standard of public services, including transport;

6. Lifestyle - leisure options, environmental and cultural assets.

The above elements combine to produce a subjective perception of a city's image, which is an unstable, internally complex and individualized category. To diagnose the actual image of a given territorial unit it is necessary to implement professional marketing research on a representative scale rather than only diagnostic surveys, which should be carried out among different groups of stakeholders, such as present and potential residents, investors, tourists and others. The identification of the existing city image should include the following elements:

- determining the target image, including a comparison of the city's image with images of its competitors based on benchmarking principles;

- determining the recipients of the city's promotional activities;

- selecting appropriate image-mix tools;

- appointing the people and units responsible for the implementation of tasks related to shaping the image;

- monitoring the activities related to developing and shaping the city's image.

The benefits of creating the image and positioning the city brand in the perception of the recipients of promotional activities include standing out from competitors, facilitating information processing as well as shaping positive attitudes towards a given destination (Ciechomski, 2019, p. 57). The main task of positioning is to consolidate a favourable image distinguishing a given city from other agglomerations. It must be remembered that municipalities, cities, districts and regions compete with one another not only for investors and tourists, but also for highly qualified employees and residents who pay taxes and identify with the place; in other words, they compete for a whole range of tangible and intangible resources.

\section{Analysis of research results on the use of city marketing tools in selected Czech destinations}

The methodological procedures used in empirical research were inspired by existing work. The research methodology is based mainly on the works of Ježek $(2005,2010)$ and Rumpel (2002). Other works important for this research are monographs by Karavatzis (2004, 2007, $2009)$ and Anholt $(2007,2010)$. The research was carried out as part of a diploma dissertation 
by Pavlína Toporska, a student of Př́rodovědecká fakulta Univerzites Karlove in Prague. In the empirical part of the work, an attempt was made to assess the use of city marketing tools in a predetermined area based on individual in-depth interviews (IDI) with representatives of the authorities of selected cities. Research targets were formulated, followed by specific research problems. The formulated research questions serve to obtain answers relating to several important areas which are at the core of contemporary city marketing practice. Most of these questions follow from both literature studies and earlier empirical research. The principal research questions included the following issues:

1. To what extent is city marketing already present in cities?

2. What are the main problems of the cities as defined by experts?

3. Are the surrounding cities competitors?

4. Which cities cooperate with the private sector and investors, and in what ways?

For the purposes of source research, a structured questionnaire was developed for interviews with respondents, who were the representatives of city authorities. A total of 12 Czech cities from the Moravian-Silesian region were included in the research. The intention was to find out how city marketing is perceived in cities of a similar size, characterized by a similar level of socio-economic development and located in the Moravian-Silesian region. In the end 7 representatives of cities submitted exhaustive answers, and this self-selection is interesting in itself. It can be philosophically observed that a lack of response is also a certain response. Also, some respondents wanted to receive the questionnaire in advance and to be able to answer the questions only in writing.

The research aimed to assess to what extent city marketing had been implemented in the cities of the Moravian-Silesian region; which tools of city marketing can be used to manage the development of a city; which cities use them; and how they evaluate those tools.

The questionnaire contained a total of 14 questions designed to check the extent to which the representatives of cities are familiar with the concept of city marketing. The questions related to general knowledge about city marketing; the segmentation of target groups and ways to communicate with them; problems with city development; marketing activities undertaken, for example, as part of cooperation with the private sector; supporting investment; and event marketing.

The research was conducted in the Czech Republic in the following cities of the MoravianSilesian region: Bohumín, Bruntál, Frýdek-Místek, Krnov, Opava, Ostrava and Třinec. For the purposes of this article, the results for the border towns of Bohumín, Opava and Třinec and the provincial capital of Ostrava are presented. The location of the region and the cities are shown on the maps below (Figure 2 and 3). 


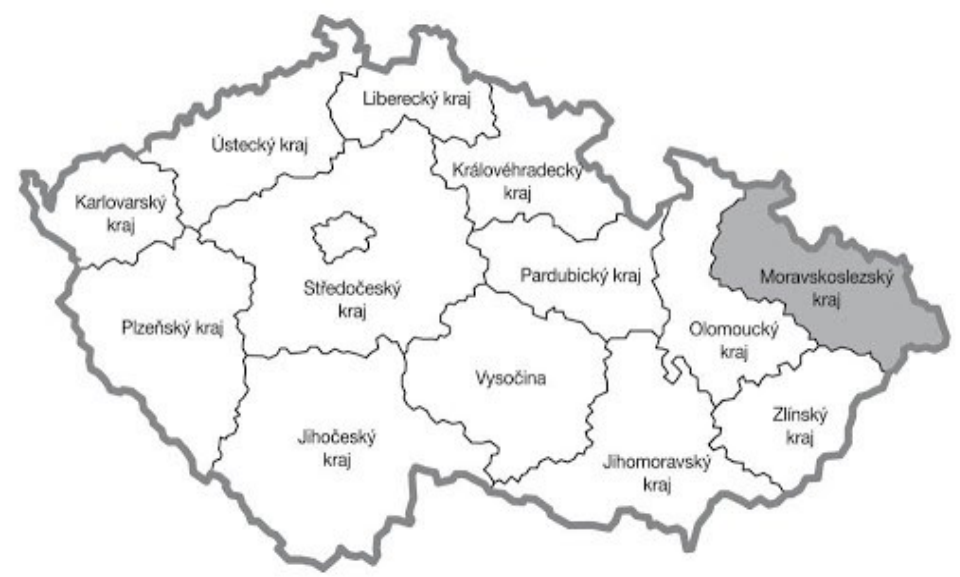

Figure 2. Location of the Moravian-Silesian region in the Czech Republic. Source: own compilation based on bing.com/images.

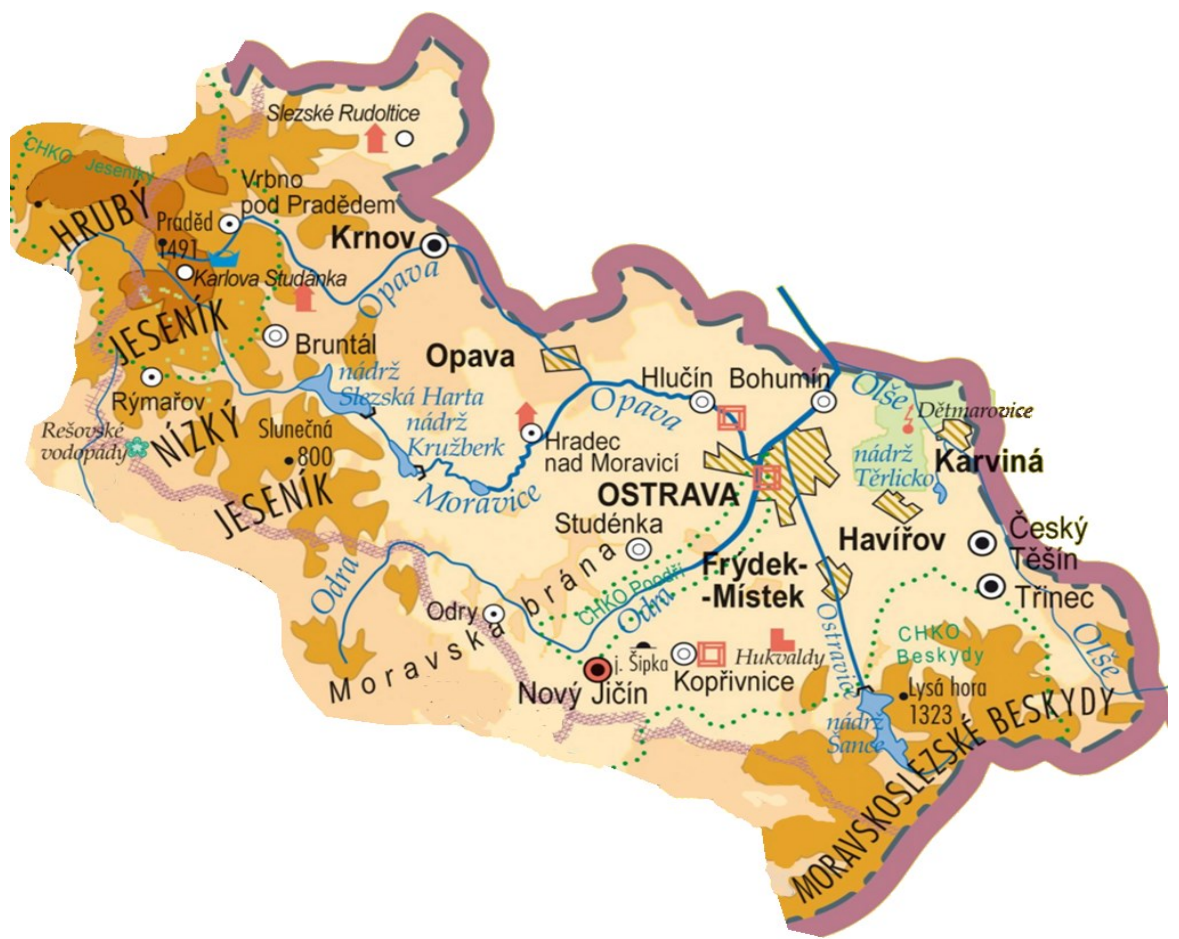

Figure 3. Location of the cities of Bohumín, Opava, Trrinec and Ostrava, where the research was conducted. Source: own compilation based on bing.com/images.

Bohumín is one of the most important railway junctions in the Czech Republic. It is located in Karvina district and according to recent data has a population of 22,000. Together with Ostrava and other nearby cities, Bohumín can be considered as the industrial centre of the region. The largest local enterprises include Rockwool, Bohumin ironworks, Biochemie and others.

Opava is the sixteenth largest city in the Czech Republic in terms of population $(58,000)$. The history of this important centre of Czech Silesia dates back to the 13th century. Today, the city is the economic centre of the entire micro-region, with some important companies based there: Ferram Strojírna, the food company Mondelez Czech Republic, the pharmaceutical company Teva Czech Industries, Model Obaly, and Optys. The city of Opava is now the seat 
of the University of Silesia, one of the state universities in the Moravian-Silesian region. In addition to being a historical city, Opava is also a commercial centre of the Czech part of Silesia as well as one of the most attractive cities in the Moravian-Silesian region. This is due to a number of events that are regularly held there (Bezručova Opava, European Heritage Days, Majáles at the University of Silesia, the Opava Cultural Summer, and others).

Trinec is the second easternmost city in the Czech Republic. It has a population of around 37,000 inhabitants and is located about $30 \mathrm{~km}$ from Ostrava. Třinec is an industrial city, being the seat of Třinecké železárny, the Třinec Iron and Steel Works, which produces over a third of all steel in the Czech Republic (around 2.5 million tonnes per year). Despite the fact that the company is one of the major employers in the region and an important partner of the city, it is also a major air polluter. As a result, the quality of the natural environment is one of the city's greatest problems. Trrinec, like the other destinations that participated in the study, supports business, for example by promoting the local Balina industrial zone. The city also accommodates many tourists, despite not being a typical tourist place. This is due to its closeness to the Moravian-Silesian Beskids, which are the primary destination for tourists visiting the region. In addition, the city regularly hosts various events which involve not only local residents. The most famous of these are the Cultural Summer and Holidays in Trrinec.

Ostrava is the capital city of the Moravian-Silesian region and has a population of almost 300,000 residents. Ostrava, like the entire Moravian-Silesian region, has long struggled with the structural problems of a post-industrial agglomeration. Some of the largest companies in the region, such as ArcelorMittal Ostrava or Vítkovice Steel, are located here, but their production is gradually being reduced. It is also necessary to transform the brownfield land in the Dolní Vítkovice area, which has become the first Czech industrial heritage site on the European cultural heritage list. The image of the city is enhanced not only by the Colours of Ostrava music festival, but also by other events such as Maj Janačka, the Summer Shakespeare Festival, and the Golden Stirrup athletics meeting.

The next part of this article analyses the respondents' answers given to the questions during in-depth interviews. The first question asked what tools the city authorities use when planning the city's development. Each of the cities participating in the study has a strategic development plan, which is constantly being updated. Actions related to crime prevention are perceived as particularly important for the development of the city, especially in Třinec and Bohumín, where they help, for example, to tackle problems with people of Romani origin living in city shelters. The city of Opava has developed an Integrated City Development Plan, as well as a strategy for foreign cooperation, a cultural development plan and a concept of funding for sports.

The aim of the second question (If you do not know the concept of city and regional marketing, what do you think it can be?) was to find out how the city authorities identify the categories of city and regional marketing. All the respondents replied that they know the concept, but sometimes use other terms to describe it. The results of the interviews also showed that the application of city marketing is now more comprehensive than it was in previous years. 
The research confirmed that city authorities treat city and regional marketing as a comprehensive approach that helps to solve the current and future development problems of cities and municipalities.

In question 3 the respondents were asked about the target groups on which they focus their marketing activities. The research showed that city authorities and the employees of the appropriate departments and organizational units often segment the recipients of marketing, and many of their activities focus on specific groups of people. Usually, however, this happens inadvertently as many employees of city offices do not realize the importance of segmenting the recipients of promotional activities. The recipients of marketing activities mentioned in the interviews included entrepreneurs, visitors, associations, interest groups, seniors and families. In addition, the authorities of Bohumin emphasized that they are currently concentrating on stopping or slowing down the emigration of young and educated residents.

Communication between cities and their inhabitants or other target groups is very important. All the surveyed respondents are aware of this. One of the problems identified in the study is the low interest in city council meetings, which only a few residents regularly attend. Nevertheless, personal communication is important for cities and all the respondents emphasised this. It is also worth mentioning the e-info service, which has been operating in Bohumín since 2002. Residents registered on this application are informed by e-mails and text messages about road closures, power and water outages, as well as planned cultural events. The respondents mentioned the following tools and channels of communication with target groups: personal meetings, Internet media, television, newspapers, employee committees, meetings with entrepreneurs, surveys, city notice boards, office notice boards, city information centres, billboards, CLV banners (City Light or City Light Showcase), advertising posters and other media.

Question 5 asked about the main problems concerning the city's development. The conducted research identified such threats as soil, water and air pollution, which mainly affect Trrinec and Bohumín. In addition, the respondents mentioned a decline in population (Bohumin), a shortage of jobs, no city bypass (Opava), a shortage of parking spaces (Třinec), and industrial pollution (Ostrava). The respondents also complained about a poor connection with the motorway network of the Czech Republic, inadequate access to public places for disabled people in wheelchairs, and a long-term negative image of the city. A pressing problem was also the insufficient interest of central institutions in the eastern region of the country, which is struggling with many issues that need to be addressed. City officials are also aware that attracting investors is often hindered by the fact that their communications are not comprehensive and effective enough to attract entrepreneurs.

In question 7 the city authorities were asked what they are proud of. The following responses were obtained: 
1. Bohumín: modernization of the housing stock; flood protection; city image; development of sports facilities; public awareness; good financial condition; success in obtaining subsidies; urban infrastructure; aesthetic public space.

2. Opava: connection to the motorway network; promotion of retail trade.

3. Třinec: modernization of the library, Via Lyžbice underground passage; development of the Balina industrial zone; revival of cultural events; parks and green areas in the city.

4. Ostrava: influx of foreign investors; development of science and technology parks and industrial zones; development of universities.

Next, the representatives of city authorities were asked if they felt the threat of competition from other cities in their vicinity or in the region. In all four cases, the answers were affirmative. In the current socio-economic conditions, competition between the largest cities in the Czech Republic is strong, and the issue of city marketing is closely related to the competitiveness of spatial units, such as cities or regions. The representatives of the studied cities noticed an increase in competitive pressure in recent years and acknowledged the need for cities to increase their comparative advantage in the medium term, which is often supported by modern marketing. The study also identified competition between cities and their peripheries. Due to the expanding urbanization and shortage of land for development in cities, there is a substantial outflow of people to suburban areas. This is an increasingly common trend. As a consequence, there is an urgent need to revitalize the city centres.

A full implementation of city marketing requires the cooperation of individual sectors. The importance of cooperation between the public and private sectors today, which to some extent determines individual areas of the region's development, is the subject of analyses by experts representing many scientific disciplines including economics, administration, regional development and political science. The surveyed cities are taking similar steps to attract potential investors. Information for entrepreneurs can be found on their websites. In this way, the local governments try to help entrepreneurs overcome the complicated bureaucratic procedures that often make it difficult to start and run a business.

Cities attach great importance to the promotion of various events: information about them can be found in local newspapers, on posters in designated city places, on roadside billboards, or in information spaces on public transport. In the case of large events, city authorities organize press conferences, which are certainly an excellent communication tool used in so-called event marketing.

The last question of the interview concerned the importance of subsidies for city development. It turns out that subsidies play a very important role in all the cities that participated in the study. However, the respondents stressed the fact that although subsidies are beneficial to the development of cities, excessive bureaucracy often discourages cities from applying for them. According to the representatives of city authorities, certain conditions for granting a subsidy (such as, for example, a long compulsory project financing time) sometimes mean that implementing the project without a subsidy is a better option. 


\section{Conclusions}

In summary, empirical research has proved the important role of the concept of city marketing in the management of selected Czech cities located in the Czech-Polish borderland. The respondents emphasized the pressure from other settlement units, even from smaller peripheral towns, in the competition for investors and tax-paying residents. Promotional activities are also directed at tourists who choose a given destination for their holidays.

Territorial marketing goes through certain stages in its evolution. It becomes enriched with new forms and instruments of communication with the environment, including those related to Internet media or mobile applications. Competition for limited resources, such as investor funding or tourism income, will be won by those cities whose authorities manage to develop and implement effective marketing strategies ahead of their rivals.

\section{References}

1. Anholt, S. (2010). Places: Identity, image and reputation. Chippenham and Eastbourne: Palgrave Macmillan, p. 168.

2. Anholt, S. (2007). Competitive Identity: A new model for the brand management of nations, cities and regions. Policy \& Practice: A Development Education Review, Vol. 4, Spring, pp. 3-13.

3. Ciechomski, W. (2017). Ewolucja i implementacja marketingu terytorialnego. Marketing i Rynek, 10, p. 120.

4. Ciechomski, W., Romanowski, R. (2016). Segmentacja nabywców produktu terytorialnego jako element budowania przewagi konkurencyjnej. Marketing i Rynek, 10, p. 82.

5. Ciechomski, W. (2019). Creating and positioning the image of a territorial unit. Scientific Papers of Silesian University of Technology, Organization and Management Series, No. 146, p. 57.

6. Ciechomski, W., Romanowski, R. (2013). Marketing terytorialny oparty na wiedzy. Poznań: Wydawnictwo Uniwersytetu Ekonomicznego, p. 63.

7. Duczkowska-Piasecka, M. (2013). Marketing terytorialny: jak podejść do rozwoju z korzyścia dla wszystkich. Warszawa: Difin, p. 145.

8. Florek, M. (2006). Podstawy marketingu terytorialnego. Poznań: Wydawnictwo Akademii Ekonomicznej, p. 76.

9. Ježek, J. (2010). Aplikace městského marketingu v praxi: vývoj, očekávání, realita (kritický pohled). E+M. Ekonomie a Management, p. 123. 
10. Ježek, J., Pauličková, R. (2005). Marketing of towns in theory and practice. Experience in applying marketing in the Czech Republic and Slovak Republic. Medzinárodná vedecká konferencia ERSA vo Vysokých Tatrách, Nový Smokovec 27-30.9.2005, KošiceBratislava: Technická univerzita Košice a Ekonomická univerzita Bratislava, pp. 159-163.

11. Łazorko, K., Niedzielska, A. (2011). Kreowanie wizerunku miejsca w koncepcji marketingu terytorialnego. Częstochowa: Wydawnictwo Politechniki Częstochowskiej, p. 15.

12. Kavaraztis, M. (2005). Branding the City through Culture and Entertainment, paper presented at the AESOP 2005 Conference, 13-18 July 2005, Vienna, Austria.

13. Kavaratzis, M. (2004). From City Marketing to City Branding: Towards a Theoretical Framework for Developing City Brands. Place Branding and Public Diplomacy, pp. 58-73.

14. Kavaratzis, M. (2007). City Marketing: The Past, the Present and Some Unresolved Issues. Geography Compass, 1, 3, s. 695-712.

15. Kavaratzis, M. (2009). What Can We Learn from City Marketing Practice? European Spatial Research and Policy, pp. 41-58.

16. Makarski, S., Kuźniar, W. (2009). Marketing w zarządzaniu jednostka terytorialna na przykładzie województwa podkarpackiego. Rzeszów: Wydawnictwo Uniwersytetu Rzeszowskiego, p. 28.

17. Rumpel, P. (2002). Teritoriální marketing jako koncept územního rozvoje. Spisy prací Přírodovědecké fakulty Ostravské univerzity 145. Ostrava: Ostravská univerzita, p. 177.

18. Rumpel, P. (2003). Lokální a regionální rozvoj - Část 3. Teritoriální marketing jako koncept lokálního a regionálního rozvoje. Ostrava: Ostravská univerzita, 2003.

19. Striš, J., Vodák, J., Kubina, M., Jankal, R., Soviar, J. (2009). Marketingové riadenie. Žilinská univerzita v Žiline, EDIS-vydavatel'stvo ŽU, p. 390.

20. Toporská, P. (2015). Analýza městského marketingu ve vybraných městech moravskoslezského kraje. Diplomová práce, UK Praha, Př́rodovědecká fakulta. 